\title{
British voters force rethink of global warming strategy
}

London. The voters of Christchurch in Hampshire gave Britain's Conservative government a sharp warning last week that fiscal instruments applied in isolation from broader social policies are unlikely to provide an acceptable strategy for combating global warming.

A key factor in the government's worst by-election defeat since 1945 was its decision in March to introduce valued added tax (VAT) on domestic heating fuel. The Treasury justified this move on the grounds that this was needed if the country was to reduce carbon dioxide emissions. But Christchurch voters were more concerned about its impact on low-income groups, particularly old-age pensioners.

Ironically, the defeat came three days after the Minister for the Environment, John Gummer, announced further measures to the same end. The government, he claimed, could now meet the commitment it made at last year's earth summit in Rio de Janeiro: to reduce carbon dioxide emissions to their 1990 levels by the year 2000 .

To meet this, Britain will have to cut such emissions by 10 million tonnes of carbon, 6 per cent of what was previously estimated. The government had planned to achieve 15 per cent of this reduction by imposing VAT on heating fuel, and a further 15 per cent by increasing taxes on petrol; these goals will have to be reconsidered following its decision to halve the planned VAT rate on heating fuel (and possibly to abandon it all together in the light of last week's defeat).

The government's main strategy so far for curbing carbon emissions has been to seek measures that "go with the grain of the market," instead of resorting to direct regulation. Measures previously announced, for example, have focused on informing individuals and businesses about ways to save energy and giving them financial incentives to do so, for example through the creation of an Energy Saving Trust.

Last week's package continued in the same vein. The main quantified target was a goal of reducing energy consumption by 20 per cent of 1990 levels that is being set to all government departments. Gummer also announced he would help the government's Energy Efficiency Office in its task of advising small businesses by creating Local Energy Advice Centres.

Many of those who support strong action to curb global warming have welcomed the new measures. But they warn that they do not go far enough in important areas, such as curbing vehicle emissions. "We felt that the government could, for example, have adjusted tax on company cars to give an incentive for greater energy efficiency," says Chris

Hampson, head of the global warming working group of the government's Advisory Committee on Business and the Environment.

Others claim that the results of the Christchurch by-election show a growing awareness that fiscal instruments alone (such as the blanket imposition of VAT on heating fuel) are not only unfair (those affected most are low-income households in which heating bills account for more of the budget) but are also not very effective. "The problem is the inelasticity in demand," says Ben Plowden, energy campaigner of the Council for the Protection of Rural England. "Those who cannot afford to improve the efficiency with which they use energy just end up paying more, not consuming less. We need an approach that combines price signals and the ability to respond to them."

Environmentalists are now joining social action groups to launch a campaign to persuade the government to adopt just such an approach. They welcome government promises to reimburse low-income families for the extra costs of heating fuel. But they also demand that it invest heavily to increase the energy efficiency of low-income households.

The political fall-out from Christchurch is expected to make the government more responsive to such arguments. So too is its wish to show other members of the European Communities that it is more desirable to reduce carbon dioxide levels by introducing carefully designed (and politically acceptable) packages of incentives in each state than to impose a blanket carbon tax.

David Dickson

\section{UK health authority suspends Allain}

London. Jean-Pierre Allain, the former head of research at the French National Centre for Blood Transfusion, was last week suspended as director of East Anglia regional blood transfusion services following his imprisonment by a French court over his role in allowing haemophiliacs to be treated with blood infected with HIV (Nature 364, 269).

Allain held a joint appointment as professor of transfusion medicine at the University of Cambridge and director of the regional blood transfusion service. Earlier this year, the health authority set up an ethics committee chaired by the philosopher Baroness Warnock. This concluded Allain had acted in a way "consistent with medical ethics" and considered that he was fit to continue in his position.

\section{Constitution torpedoes French university reform}

Paris. A bill that would have given French universities a greater say in their own affairs was scrapped last week because it conflicted with the constitution. Parliament had adopted it by a majority early last month.

The bill would have let universities opt out of the 1984 Savary law. This specifies national norms for such things as the appointment and role of a university council, and the statutes and financial and organizational structure of a university.

The constitutional council ruled that the bill was illegitimate because it would have let universities fix their rules: article 34 of the constitution says only parliament can do this. It also ruled that the bill threatened the constitutional liberty and independence of university teachers by letting outsiders onto university councils.

François Fillon, minister for higher education and research, last week expressed his "regret" at the decision. He must have been surprised too. The bill was a clever alternative to attempting to replace the Savary law completely and to impose autonomy on the universities: it was meticulously engineered to ensure that reforms gained momentum gradually while avoiding dissent among university teachers and student opposition on the streets (see Nature 364, 5; 1993).

The government's advisers had assured it that the bill did not conflict with the constitution. The only constitutional route to giving the universities greater autonomy now open to Fillon is to remove the Savary law from the legislature. And last week he announced his intention to do so after the parliamentary elections in 1995: as "the only way to modernize French universities".

Declan Butler
However the regional health authority now says it would be "inappropriate" to continue to pay Allain as he is "unavailable to conduct his duties". The University of Cambridge says it has granted Allain leave of absence. Both the university and the health authority say they will reconsider their position in the autumn, after the French Supreme Court decides whether to grant Allain a further appeal.

Since Allain's imprisonment, his British colleagues have spoken out against the verdict. In a letter to the Lancet (24 July), 37 staff from the department of haematology at the University of Cambridge describe the verdict on Allain as 'bizarre' and promise that they will "work to right this injustice."

Declan Butler 